\title{
深絞り加エにおけるブランク形状と分割可変ブランクホルダーカの同時最適化
}

\author{
河本 基一郎 ${ }^{* 1}$, 宮坂 卓嗣*1, 山道 顕*1, 野田 拓也*1 \\ 北山 哲士 ${ }^{* 2}$, 小山 浩季*3, 山崎 光悦 ${ }^{* 4}$
}

\section{Design optimization of initial blank shape and segmented variable blank holder force trajectories in deep drawing}

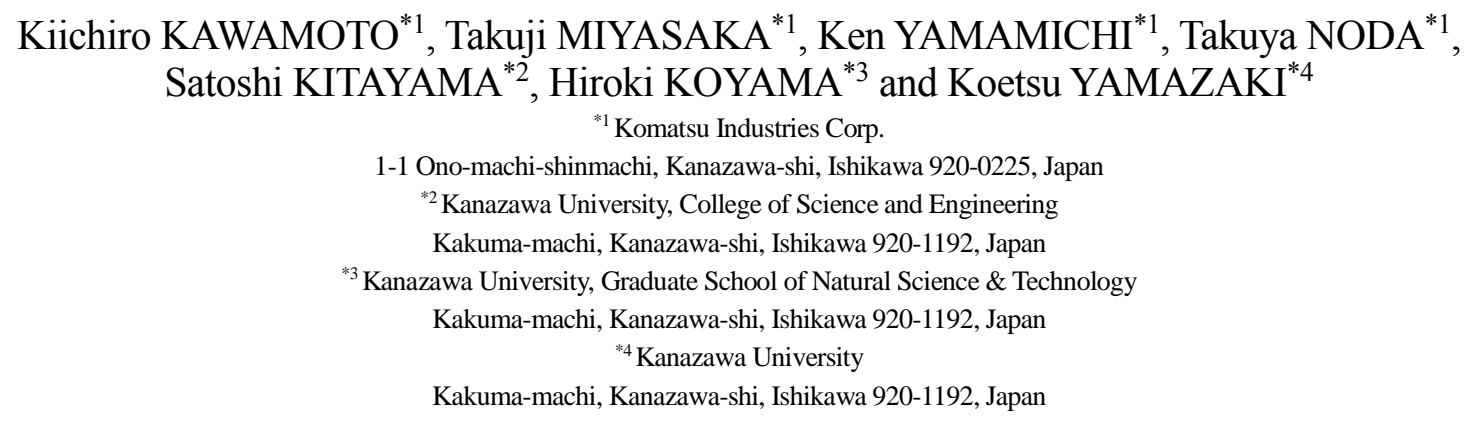

Received: 11 October 2016; Revised: 8 November 2016; Accepted: 8 December 2016

\begin{abstract}
Blank shape minimizing earing, which is trimmed off after forming, is an important issue in sheet metal forming. In addition, blank holder force (BHF) have an influence on the product quality. Recently, variable BHF (VBHF) that the BHF varies through punch stroke is recognized as one of the advanced forming technologies. Furthermore, segmented VBHF will be valid to complex shapes for successful sheet metal forming. However, the optimal segmented VBHF trajectories and the optimal blank shape minimizing the earing are unknown in advance, and consequently the trial and error method is widely used to determine them. To resolve above issues, in this paper, a simultaneous design optimization of the blank shape and the segmented VBHF trajectories is performed. Numerical simulation in sheet metal forming is so intensive that a sequential approximate optimization using a radial basis function network is adopted to determine them. Based on the numerical result, the experiment using AC servo press is carried out. It is confirmed from the numerical and experimental result that the proposed approach is valid.
\end{abstract}

Key words : Deep drawing, Plastic forming, Enginering optimization, Numerical simulation, Sequential approximate optimization

\section{1. はじめに}

自動車部品やシンクなど多くの工業製品は, 深絞り加工によって成形される. 深絞り加工では, 薄板(ブランク) をダイとブランクホルダーに挟み，材料を押さえるブランクホルダーカ(Blank holder force: BHF)を作用させ，金 型間にブランクを流入させることで所望の立体形状を得る. 加工時間が短いため高い生産性を有しており，複雑 形状の成形が容易なため，産業上重要な生産技術の一つである。しわや割れといった代表的な成形不良なく成形 するために，金型形状や潤滑状態，BHF など複数の成形パラメータを調整する．その中でも特に BHF はプレス 機での調整が容易な成形パラメータであるが，試行錯誤的に決められていることが多く，また成形中に一定の

No. 16-00485 [DOI: 10.1299/transjsme.16-00485], J-STAGE Advance Publication date : 19 December, 2016

*1 正員，コマツ産機（株）（广920-0225 石川県金沢市大野町新町 1-1）

*2 正員，金沢大学 理工研究域（广920-1192 石川県金沢市角間町）

*3 正員, 金沢大学大学院自然科学研究科

*4 正員, フェロー, 金沢大学

E-mail of corresponding author: kitayama-s@se.kanazawa-u.ac.jp 
BHF を用いていることがほとんどであろう.

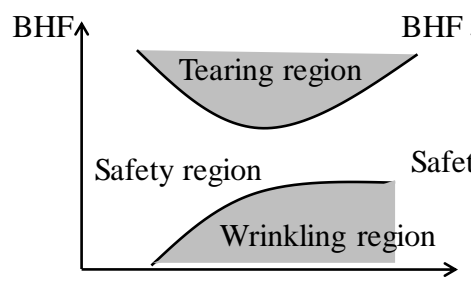

(a)
Stroke

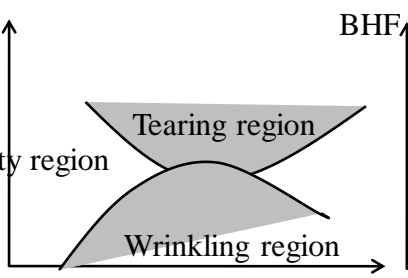

(b)

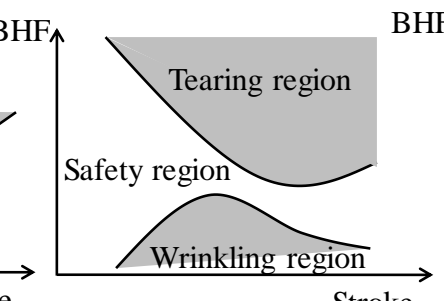

(c)

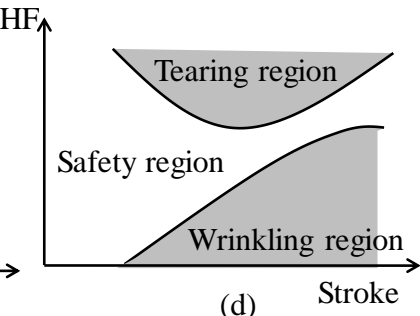

Fig. 1 Basic formability window proposed by Wang et al.

Wang らは，基本的な成形性を，図 1 に示すストロークとBHF の関係に変換した Formability window という形 で整理している(Wang et al., 2007). 同図(a)において，BHF が高いと割れを発生し，低いとしわを発生してしまう ため，同図中の Safety region を通るような BHF を見つけることが重要となる. また同図(b)においては，しわ領域 と割れ領域が交差する点でしわと割れが同時に発生してしまうため，これ以上深く絞ることはできない，一方， 図 1 (c) (d)の場合, 深く絞るためには, ストロークに応じて BHF を変化させる可変ブランクホルダーカ(Variable blank holder force: VBHF)による成形が有効であることを示している．しかし，Formability window は成形対象や材 料等によって変化するため，それらに応じた，成形不良のないVBHF の軌道を決定することが重要となる．深絞 り加工を対象にしたVBHFの軌道に関する研究は大きく, PIやPID制御を用いた閉ループアルゴリズムを構築し, しわや割れを発生しない VBHF の軌道を決定する研究(Lo and Yang, 2004; Sheng et al., 2004; Lin et al., 2007; Wang et al., 2007) と, 応答曲面を用いて様々な目的関数や制約条件の下で VBHF の最適軌道を決定する研究(Jakumeit et al., 2005; Wang et al., 2008; Kitayama et al., 2012; Kitayama et al., 2013; Kitayama et al., 2015)に分類することができる. こ れら二つのアプローチの相違点等については文献(Kitayama et al., 2012)に詳述してあるので参照されたい.

薄板成形の深絞り加工においては，上述の通り，しわや割れを発生しないような VBHF の軌道を決定すること が一つの研究課題となるが, 成形不良なく成形できた後, 次の加工ステップでは, フランジ部に生じる部分(一般 には耳と呼ばれる材料の余剩部分で, 以降, 耳と記述)をトリムライン(切り取り線)に沿って切り落とす. 材料コ ストの観点から，成形後に生じる耳を最小とするような初期ブランク形状を決定することも重要な研究課題であ り，例えば Park らは幾何形状誤差(Geometrical shape error: GSE)檤入し，トリムラインと変形後のブランク外周 の距離を評価し，これが十分小さくなるまで有限要素解析を繰り返す閉ループ型アルゴリズムを提案している (Part et al., 1999). GSE を用いたブランク形状最適化に関する研究は盛んに行われているが(Wang et al., 2009; Vafaeesefat, 2011; Fazli and Arezoo, 2012), GSE ではブランク外周がトリムラインの内側か外側かを判断できないと いう問題点を抱えているため, Oliveira らは新たに目標形状誤差(Target shape error: TSE)導入して, ブランク形 状最適化を行っている. TSE では, ブランク外周上の点がトリムライン内側にあるか外側にあるかを判断し, TSE を最小とするような閉ループ型アルゴリズムを構築しているため，ブランクの変形形状はトリムラインに沿うよ うな初期ブランク形状を得ることができる。しかし，一般に薄板成形シミュレーションは計算負荷が高いため， 閉ループを構築する方法では多くの計算回数を必要とする.一方で, 応答曲面による方法では, TSEや GSEによ る方法に比ベトリムラインに極力沿うような精度の高い初期ブランク形状は得られないものの, 計算回数を劇的 に削減でき，ブランク形状の初期検討が早期にできるなど，設計という視点では利点が多いと考えられる．応答 曲面を用いた初期ブランク形状の最適化の研究として, 二次近似による応答曲面を段階的に更新し, 耳を最小と するような初期ブランク形状を決定した研究(Hino et al., 2006)や, GSE をニューラルネットワークで近似し, 最適 化を適用することで初期ブランク形状を決定した研究(Chamekh et al., 2010), Support Vector Regression(SVR)を用い て成形不良なく最小ブランク面積となるような多角形のブランク形状を決定する研究(Liu et al., 2013)などが挙げ られる.いずれの研究においても, BHF は事前に決められた一定值が用いられており，VBHFによるアプローチ は検討されていないことに注意されたい.

自動車部品のような複雑形状を対象とした絞り加工においては, ブランクホルダーを分割し，各ブランクホル ダーに独立な BHF を作用させ，材料の流入を部分的に制御する分割ブランクホルダーカ(Segmented blank holder force: S-BHF)による成形の有効性が指摘されている(Wang et al., 2007). ブランクホルダーを分割しない場合の 
VBHFによる成形の有用性が検証されつつある状況において, ストロークに応じて S-BHF を変化させる分割可変 ブランクホルダーカ(Segmented variable blank holder force: S-VBHF)による成形性を検証することは, 学術研究とし ては先進的な取り組みであり，また産業応用上も適用範囲が広い重要な生産技術開発である。しかし図 1 に示し た Formability window は事前には不明であり，成形する形状にも大きく依存する．また， Safety region を通るよう な VBHF は無数に存在するため, S-VBHF の軌道を決定することはVBHF を決定すること以上に困難を極める. S-VBHF ではブランクホルダーが分割されているため, 各ブランクホルダーに対するVBHF の軌道設計が極めて 複雑になることに注意されたい，さらに，耳を小さくするような初期ブランク形状の最適化までを考慮した研究 は筆者らの調べる限り行われていない，以上を踏まえ，本論文での論点をまとめると以下のようになる.

1. しわや割れが発生しないような分割可変ブランクホルダーカの最適軌道を決定する. 図 1 中の Safety region を通る分割可変ブランクホルダーカは無数に存在するため, 最適設計問題として定式化することで, 有限 に落とし込み, 問題の解決を図る.

2. 上記に加え, 成形後に生じる耳を小さくするような初期ブランク形状も同時に決定する. 寸なわち, 初期 ブランク形状と分割可変ブランクホルダーカの最適軌道を同時に決定する.

3. 薄板成形シミュレーションは計算負荷が高いため, 筆者らが開発した Radial basis function (RBF)ネットワ ークによる逐次近似最適化システム(Kitayama et al., 2011)を最適設計支援ツールとして活用する.

4. シミュレーションにとどまることなく，その有効性について，AC サーボプレス(H2W300，コマツ産機)を 用いて検証する.

以降, 2 章において本論文で用いる有限要素解析モデルについて示し, 3 章において初期ブランク形状と分割可 変ブランクホルダーカの同時最適設計問題や計算の流れについて記述する. 4 章で数值シミュレーション結果を

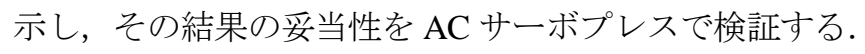

\section{2. 有限要素解析モデル}

\section{$2 \cdot 1$ 分割ブランクホルダー}

はじめに，本論文で対象とする製品のパンチと分割ブランクホルダーを図 2 に示寸. 同図に示寸通り, ブラン クホルダーは分割されており, BHFが各ブランクホルダー(Blank holder ${ }_{1}$ と Blank holder $\left.{ }_{2}\right)$ に独立に作用する. また, 各ブランクホルダーに作用する $\mathrm{BHF}$ をそれぞれ， $\mathrm{BHF}_{1}, \mathrm{BHF}_{2}$ と表記する.

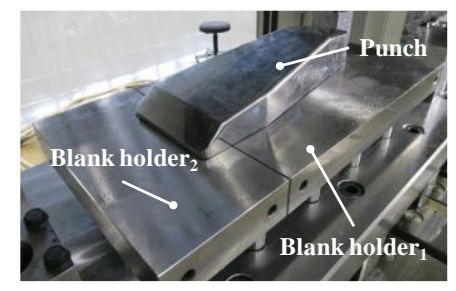

Fig. 2 Segmented blank holder

\section{$2 \cdot 2$ 有限要素解析モデルの作成}

全ストロークは $75 \mathrm{~mm}$ であり, 初期ブランクサイズは板厚 $0.8 \mathrm{~mm}$, 長さ $650 \mathrm{~mm}$, 幅 $380 \mathrm{~mm}$, 材料は SUS304 を用いた． $\mathrm{BHF}_{1}=\mathrm{BHF}_{2}=40 \mathrm{kN} \sim 120 \mathrm{kN}$ まで $20 \mathrm{kN}$ きざみで一定 BHF を作用させて実験を行ったが，すべての実 験において，しわや割れが生じる結果となった，そこで， $\mathrm{BHF}_{1}=\mathrm{BHF}_{2}$ として VBHF による成形や $\mathrm{BHF}_{1}$ と $\mathrm{BHF}_{2}$ に異なる BHFを与えて成形を試みたが，しわや割れが生じる結果となった．これらの結果から, 図 2 に示したモ デルは, S-VBHFによる成形が有用であるモデルと考えられる.そこで一定BHFの実験結果を利用して, LS-DYNA により図 3 に示寸有限要素解析モデルを作成した. 解析モデルは, 対称性を考慮し，1/2 とした. 同図中におい て nelm は要素数を表しており, パンチは固定されており, ダイに $z$ 軸負方向に強制変位を与える. 解析時間短縮 のため, ダイの移動速度は約 $8700 \mathrm{~mm} / \mathrm{s}$ としたが，ブランクのひずみ速度依存性は無視し，マススケーリングは 使用していない．また $\mathrm{BHF}_{1}$ と $\mathrm{BHF}_{2}$ は $z$ 軸正方向に与える．ダイ，パンチ，ブランクホルダーは剛体でモデル化 し, ブランクには Belytschko-Tsay シェル要素を用いた. 板厚方向の積分点数は 9 点であり, 接触ペナルティ係数 
は 0.1, ダイとブランク, パンチとブランク,ブランクホルダーとブランクの間の摩擦係数はすべて 0.15 とした. 表 1 に材料定数等を示す．なお，材料の加工硬化には， $n$ 乗硬化を用いた.

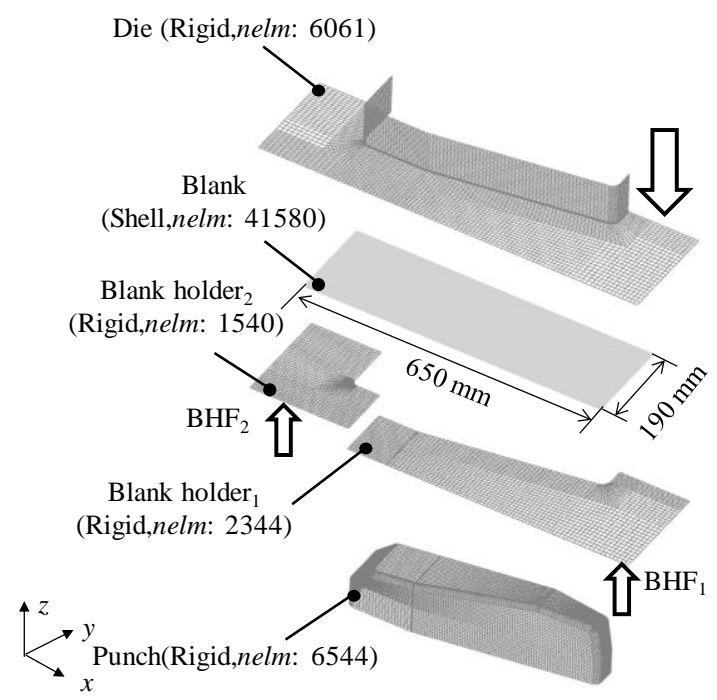

Table 1 Material property of SUS304

\begin{tabular}{l|c|}
\hline $\begin{array}{l}\text { Full blank size }[\mathrm{mm}] \\
(\text { Thickness } \times \text { Length } \times \text { Width) }\end{array}$ & $0.80 \times 650 \times 380$ \\
\hline Density: $\rho\left[\mathrm{kg} / \mathrm{mm}^{3}\right]$ & $7.93 \times 10^{-6}$ \\
\hline Young's modulus: $E[\mathrm{MPa}]$ & $2.13 \times 10^{5}$ \\
\hline Poisson's ratio: $v$ & 0.26 \\
\hline Yield stress: $\sigma_{Y}[\mathrm{MPa}]$ & 294 \\
\hline Normal anisotropy coefficient: $r$ & 1.00 \\
\hline Strain hardening coefficient: $N$ & 0.47 \\
\hline
\end{tabular}

Fig. 3 Finite element analysis model

\section{$2 \cdot 3$ 有限要素解析モデルの妥当性}

本論文では, 成形限界線図(Forming limit diagram: FLD) と引き込み量を用いて有限要素解析モデルを作成した. 紙面の都合上，代表的と考えられる $\mathrm{BHF}_{1}=\mathrm{BHF}_{2}=40 \mathrm{kN}$ と $\mathrm{BHF}_{1}=\mathrm{BHF}_{2}=120 \mathrm{kN}$ のときの比較結果を図 4(a) (b)に, 引き込み量に関しては図 5 に示寸代表的な寸法誤差(\%)を表 2 に示寸.

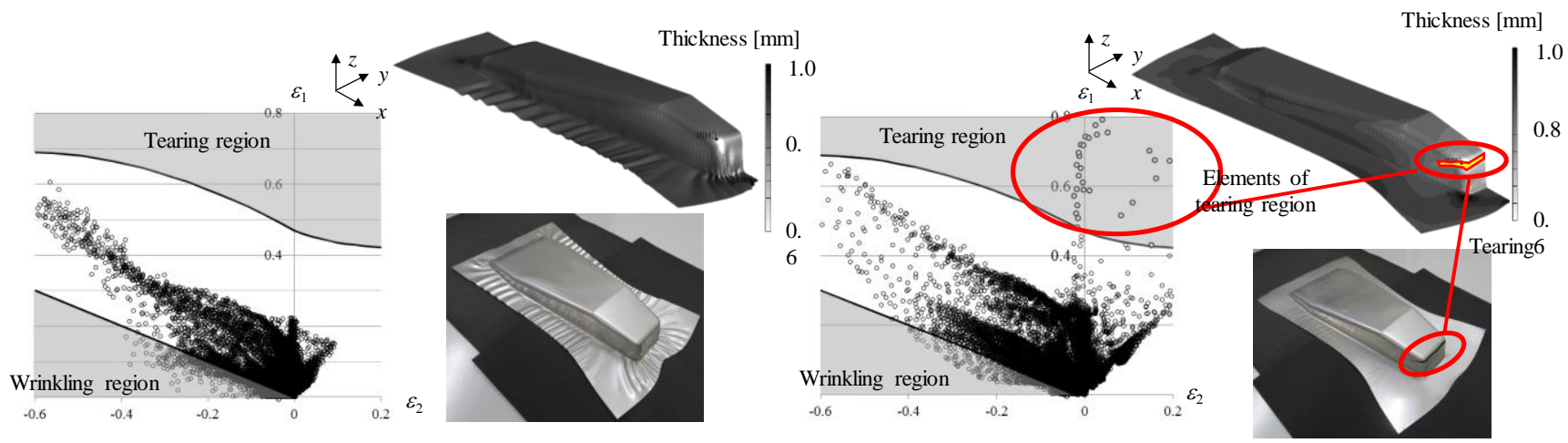

(a) $\mathrm{BHF}_{1}=\mathrm{BHF}_{2}=40 \mathrm{kN}$

(b) $\mathrm{BHF}_{1}=\mathrm{BHF}_{2}=120 \mathrm{kN}$

Fig. 4 Comparison between numerical and experimental result

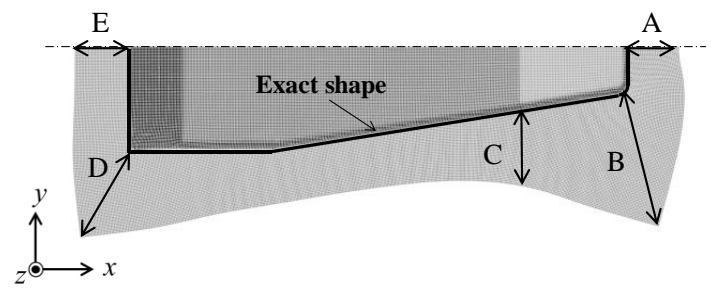

Table 2 Dimension error [\%]

\begin{tabular}{l|c|c|c|c|c}
\hline & A & B & C & D & E \\
\hline $\mathrm{BHF}_{1}=\mathrm{BHF}_{2}=40 \mathrm{kN}$ & 19.7 & 4.8 & 2.9 & 3.9 & 3.6 \\
\hline $\mathrm{BHF}_{1}=\mathrm{BHF}_{2}=80 \mathrm{kN}$ & 11.1 & 2.2 & 1.5 & 1.9 & 0.0 \\
\hline $\mathrm{BHF}_{1}=\mathrm{BHF}_{2}=120 \mathrm{kN}$ & 3.8 & 0.7 & 3.0 & 1.9 & 0.0 \\
\hline
\end{tabular}

Fig. 5 Measurement for dimension accuracy

図 4(a)では実験ではしわが発生していることが確認でき, またシミュレーションにおいても, しわが発生して いる．また FLDを見ると，しわ領域(Wrinkling region)に多くの有限要素がプロットされている．割れが発生した 図 4(b)では, 赤丸で囲った領域に示すように, 割れ発生領域(Tearing region)にプロットされた有限要素の位置と実 
験結果が定性的に一致している. 実験ではフランジ部にしわの発生がみられたが，FLDでもしわ領域に有限要素 がプロットされていることから，実験結果とある程度の整合性は取れていることがわかる．表 2 において， $\mathrm{BHF}_{1}=\mathrm{BHF}_{2}=40 \mathrm{kN}$ では，A部の寸法誤差が若干大きいが，ここはしわの発生が顕著な箇所であり，金型間への材 料流入が実験とシミュレーションで異なるためである，他においては，寸法誤差も小さいことから，作成した有 限要素モデルは妥当であると言えよう.

\section{3. 初期ブランク形状と分割可変ブランクホルダーカの同時最適設計}

はじめに述べたように，しわや割れといった成形不良なく成形するための S-VBHF の軌道は無数に存在する. また，S-VBHF の軌道決定のみならず，耳を最小とするような初期ブランク形状も同時に決めることは困難を極 める. 本論文では最適設計問題として定式化することで, 有限な次元に落とし込み, 問題の解決を図る. 以下, 目的関数や制約条件の評価方法や設計変数の取り方について詳述する.

\section{$3 \cdot 1$ 目的関数}

成形後のシミュレーションの状況を図 6 に示す，同図において，トリムライン(破線)は製品の外形(Exact shape) から $15 \mathrm{~mm}$ に設定した．これより外の部分の面積を耳として考え，最小化する目的関数 $f(x)$ とする.

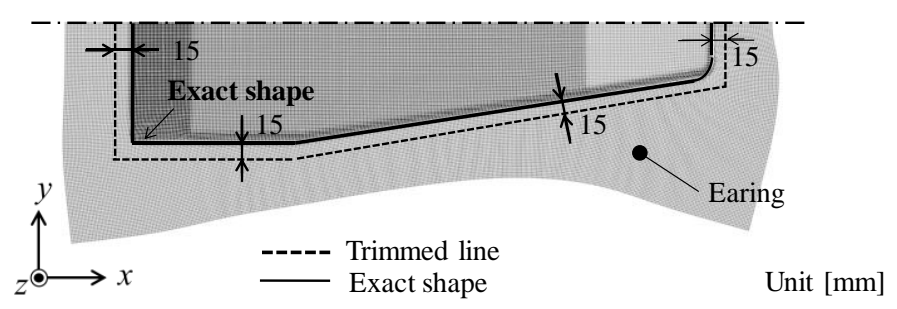

Fig. 6 Illustrative example of objective function

\section{$3 \cdot 2$ 設計変数}

設計変数 $\boldsymbol{x}$ は，ブランク形状を決定する部分 $\boldsymbol{x}_{S}$ と, S-VBHF の最適軌道を決定する部分 $\boldsymbol{x}_{T}$ から構成するものと した. すなわち, $\boldsymbol{x}=\left(\boldsymbol{x}_{S}, \boldsymbol{x}_{T}\right)^{T}$ と表記される. はじめにブランク形状に関する設計変数 $\boldsymbol{x}_{S}$ について図 7 を用いて 説明する. ブランク形状に関しては, 図 7 中の 6 つの制御点を設計変数 $\boldsymbol{x}_{s}=\left(x_{1}, x_{2}, \cdots, x_{6}\right)$ とした. 具体的には, $x_{1}$ と $x_{6}$ は $x$ 軸方向のみ, $x_{3}$ と $x_{4}$ は $y$ 軸方向のみに移動を許容し， $x_{2}$ と $x_{5}$ は破線で示寸初期ブランク形状の頂点を 結ぶ直線方向のみに移動するものとした.

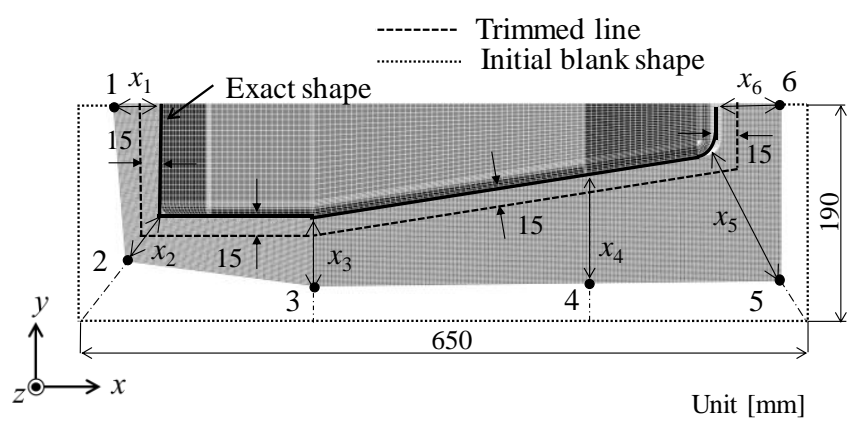

Fig. 7 Design variables for blank shape

次に S-VBHF の最適軌道を決定するための設計変数 $\boldsymbol{x}_{T}$ にいて述べる. 分割ブランクホルダーカの場合, ブラ ンクホルダー間のバランスを維持する等の諸条件から，次のような制約が課せられる.

$$
B H F_{1}=\alpha_{\max } \times B H F_{2} \quad\left(\text { or } B H F_{2}=\alpha_{\max } \times B H F_{1}\right)
$$


ここで $\alpha_{\text {max }}(>1)$ は片側の最大 BHF を規定する係数である. 上式は, 片側の BHF の最小值と最大值は, もう片 方の BHFに規定されることを意味しており, 例えば $\alpha_{\text {max }}=1.3$ とすると, $\mathrm{BHF}_{1}=30 \mathrm{kN}$ が作用している場合, $\mathrm{BHF}_{2}$ の範囲は $23.1 \mathrm{kN}(=30 / 1.3)$ to $39 \mathrm{kN}(=30 \times 1.3)$ の間で設定する必要があり, また $\mathrm{BHF}_{2}=60 \mathrm{kN}$ が作用している場合, $\mathrm{BHF}_{1}$ の範囲は $41.2 \mathrm{kN}(=60 / 1.3)$ から $78 \mathrm{kN}(=60 \times 1.3)$ の間で設定する必要がある(その逆も成立することに注意さ れたい). このような条件の下で, S-VBHF の軌道を決定する方法を考える. 具体的には, 図 1 のブランクホルダ 一1のVBHF の軌道に対し, 式(1)を考慮した形で S-VBHF の軌道を決定する.ブランクホルダー 1 に対する VBHF の軌道に対しては, 全ストロークを $M$ 分割し, 分割した位置(図 8 中 $L_{1}, L_{2}, \cdots, L_{M-1}$ ) と第 $k$ 番目のサブストローク の $\mathrm{BHF}\left(B H F_{1, k}\right.$ と表記)を設計変数とする(図 8 参照). 次に式(1)を考慮したブランクホルダー2 の VBHF を決定す ることを考えるが, 式(1)は, ブランクホルダー2 の VBHF は図 8 の灰色部分 $\left(1 / \alpha_{\max } \sim \alpha_{\max }\right)$ に収まらなければなら ないということを意味している. そこで， $1 / \alpha_{\max } \sim \alpha_{\max }$ の未知係数(設計変数) $\beta_{k}$ を導入すれば, ブランクホルダ -2 の第 $k$ 番目のサブストロークの $\operatorname{BHF}\left(B H F_{2, k}\right.$ と表記 $)$ は

$$
\left.\begin{array}{l}
B H F_{2, k}=B H F_{1, k} \times \beta_{k} \\
\frac{1}{\alpha_{\max }} \leq \beta_{k} \leq \alpha_{\max }
\end{array}\right\} \quad k=1,2, \cdots, M
$$

と書くことができ，これにより S-VBHF の軌道を表現することができる．最終的に，S-VBHF の最適軌道のた めの設計変数 $\boldsymbol{x}_{T}$ は次のようになる.

$$
\boldsymbol{x}_{T}=\left(L_{1}, L_{2}, \cdots, L_{M-1}, B H F_{1,1}, B H F_{1,2}, \cdots, B H F_{1, M}, \beta_{1}, \beta_{2}, \cdots, \beta_{M}\right)
$$

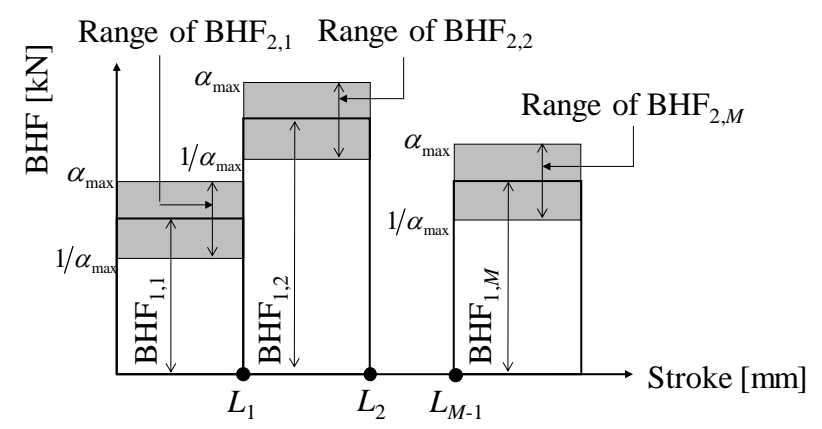

Fig. 8 Design variables for segmented variable blank holder force trajectories

\section{$3 \cdot 3$ 制約条件}

最後に制約条件とその評価方法について記述する。しわと割れは成形不良になるため，これらは避けるべき条 件として考え，制約条件として扱う。また，これらの定量化にはFLDを用いたので，その算出方法について図 9 を用いて説明する.

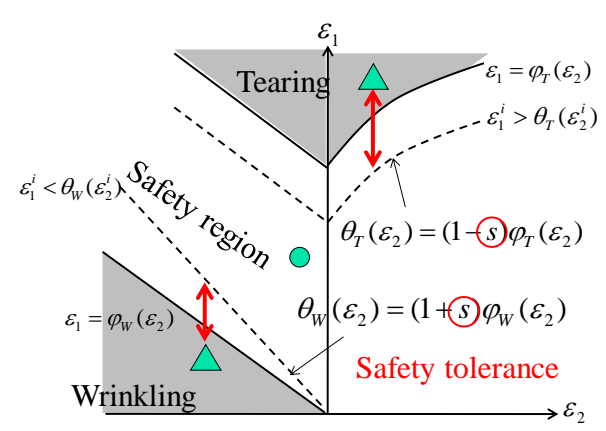

Fig.9 Forming limit diagram for evaluating wrinkling and tearing 
図 9 中において，しわの危険性が予測される有限要素は，しわ領域(Wrinkling region)にプロットされ，一方，割 れの危険性が予測される有限要素は, 割れ領域(Tearing region)にプロットされる.また，しわや割れがないと予測 される有限要素は, 安全領域(Safety region)の中にプロットされる. 主ひずみ $\varepsilon_{1}$ は,

$$
\varepsilon_{1}=\varphi_{T}\left(\varepsilon_{2}\right) \quad \varepsilon_{1}=\varphi_{W}\left(\varepsilon_{2}\right)
$$

と表記される．ここで $\varphi_{T}$ は，割れを制御する成形限界曲線(Forming Limit Curve: FLC)を表し， $\varphi_{T}$ と $\varphi_{W}$ は用い る材料に依存する．ここで，安全係数 $s$ を考慮した次の関数を考える.

$$
\theta_{T}\left(\varepsilon_{2}\right)=(1-s) \varphi_{T}\left(\varepsilon_{2}\right) \quad \theta_{W}\left(\varepsilon_{2}\right)=(1+s) \varphi_{W}\left(\varepsilon_{2}\right)
$$

そして，しわの危険性に関する制約条件 $g_{1}(\boldsymbol{x})$ は，

$$
g_{1}(\boldsymbol{x})=\left(\sum_{j=1}^{n e l m} W_{j}\right)^{1 / p} \quad\left\{\begin{array}{cc}
W_{j}=\left(\theta_{W}\left(\varepsilon_{2}^{j}\right)-\varepsilon_{1}^{j}\right)^{p} & \varepsilon_{1}^{j}<\theta_{W}\left(\varepsilon_{2}^{j}\right) \\
W_{j}=0 & \text { Otherwise }
\end{array}\right.
$$

として評価し，割れの危険性に関する制約条件 $g_{2}(\boldsymbol{x})$ は，

$$
g_{2}(\boldsymbol{x})=\left(\sum_{j=1}^{n e l m} T_{j}\right)^{1 / p} \quad\left\{\begin{array}{cc}
T_{j}=\left(\varepsilon_{1}^{j}-\theta_{T}\left(\varepsilon_{2}^{j}\right)\right)^{p} & \varepsilon_{1}^{j}>\theta_{T}\left(\varepsilon_{2}^{j}\right) \\
T_{j}=0 & \text { Otherwise }
\end{array}\right.
$$

として評価する．式(6), (7)の意味であるが，しわの危険性がある場合，有限要素 $j$ が $\theta_{W}\left(\varepsilon_{2}^{j}\right)$ よりも下にプロッ

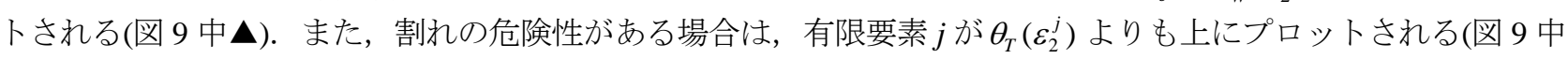
口). 安全領域にプロットされた有限要素に対しては評価值 0 を割り当て, しわ領域や割れ領域にプロットされた 有限要素に対しては， $\theta_{W}\left(\varepsilon_{2}^{j}\right)$ や $\theta_{T}\left(\varepsilon_{2}^{j}\right)$ からの距離を危険度として評価する，そして，ブランクのすべての有限 要素の総和をとることで, しわと割れの危険性を定量評価する. 式(6), (7)中の $p$ はパラメータであり, $p=4$ とし た(Wang et al., 2010; Kitayama et al., 2012).

本論文では, 初期ブランク形状の最適化も併せて考えており，例えば図 10 に示すような初期ブランク形状を考 えた場合, 同図(b)のように変形する. このとき, トリムラインを下回った面積が生じてしまう可能性があるが, このような状況を避けるため, 第三の制約条件 $g_{3}(\boldsymbol{x})$ として, トリムラインを下回った場合はその面積(正值)を制 約条件值として与えた，なお，下回った部分の面積がない場合はゼロを割り当てている.

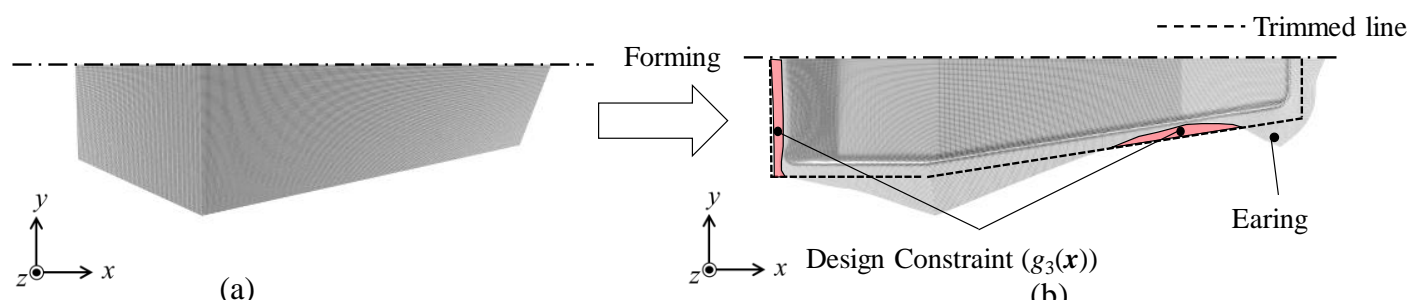

(a)

(b)

Fig.10 In the case of generating area below trimmed line

\section{$3 \cdot 4$ 逐次近似最適化を用いた同時最適化の計算の手順}

本節では，RBF ネットワークを用いた逐次近似最適化を用いた同時最適化の計算手順について簡単にまとめる.

STEP1: Latin Hypercube Design (LHD)により, 初期サンプル点(計算を行うための設計変数の組み合わせ)を決 める.

STEP2： LS-DYNA でシミュレーションを行い，サンプル点における目的関数值と制約条件值を算出する.

STEP3: RBF ネットワークによる応答曲面を構築し, 応答曲面の最適解を求める.

STEP4: 終了条件を満足していれば終了. そうでなければ，応答曲面の最適解をサンプル点として追加する. 
STEP5：現時点のサンプル点をすべて用いて，サンプル点の疎な領域を見つけるための密度関数を構築し，最 適化をする. 密度関数の最適解をサンプル点として追加する.

STEP6: STEP2 へ戻る.

STEP5 を何回か繰り返すことで，サンプル点の疎な領域を段階に見つけ，新たなサンプル点として追加するこ とで大域的な様相の把握が可能となる. また, STEP4では STEP3 で得られた応答曲面の最適解を追加するため, 局所的精度の向上を狙っている．全体の流れを図 11 に示寸．応答曲面や密度関数の最適解探索には Differential Evolution(DE)を用いた．詳細は，文献を参照されたい(Kitayama et al., 2013).

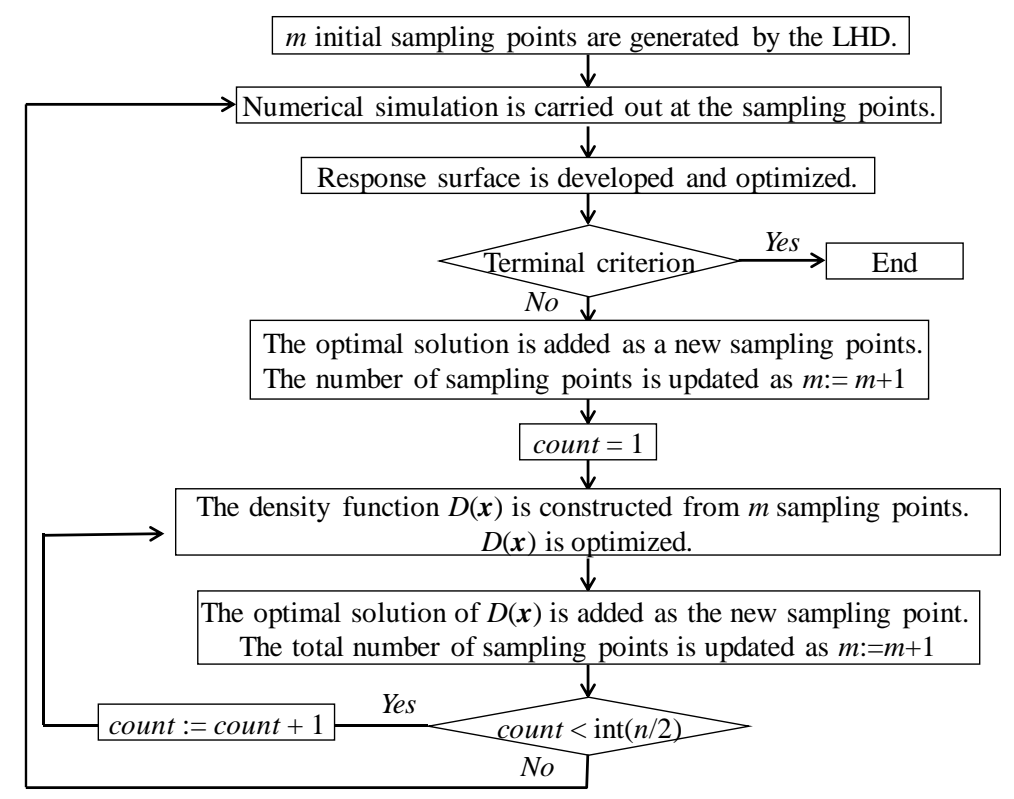

Fig. 11 Flow of sequential approximate optimization using radial basis function network

\section{4.シミュレーションおよび検証実験結果}

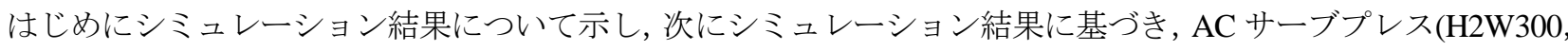
コマツ産機)を用いた実験結果を示す。

\section{$4 \cdot 1$ シミュレーション結果}

全ストロークが $75 \mathrm{~mm}$ であることを考慮し，ストロークを 3 分割した．また，設計変数の側面制約条件は式(8), (9)のように設定した。

$$
\begin{aligned}
& \left.\begin{array}{ccc}
19 \leq x_{1} \leq 45 & 30 \leq x_{2} \leq 60 & 48 \leq x_{3} \leq 70 \\
75 \leq x_{4} \leq 120 & 48 \leq x_{5} \leq 90 & 45 \leq x_{6} \leq 63.5
\end{array}\right\} \\
& 10 \leq L_{1} \leq 45 \quad 50 \leq L_{2} \leq 73 \\
& \left.40 \leq B H F_{1, k} \leq 140 \quad \frac{1}{1.3} \leq \beta_{k} \leq 1.3 \quad k=1,2,3\right\}
\end{aligned}
$$

ここで, 式(8)はブランク形状に関する設計変数 $\boldsymbol{x}_{s}$ であり, 図 7 中の Exact shape を原点ラインとした. また式(9) は S-VBHF の最適軌道のための設計変数 $\boldsymbol{x}_{T}$ であり, 式(3)に対応する. なお, 式(2)において $\alpha_{\text {max }}=1.3$ とした. 逐 次近似最適化では，応答曲面の最適解における目的関数值と制約条件值の誤差が $5 \%$ $\%$ 下となったときに終了す るものとした. 初期サンプル点を 35 点とし, 最適解を得るまでに 63 点を要した(すなわち, 最適解を得るまでに 63 回のシミュレーションを要した).

最適化の結果，得られた初期ブランクの最適形状とその変形後の形状を図 12 に，また S-VBHF の最適軌道を 図 13 に示寸.図 13 において, 実線は図 1 の Blank holder 1 の VBHF の最適軌道( $\mathrm{VBHF}_{1}$ と表記), 破線は Blank holder 2 
の VBHF の最適軌道 $\left(\mathrm{VBHF}_{2}\right.$ と表記)をそれぞれ表している. 図 12 から，初期ブランクの最適形状はほぼ金型に 沿ったような形となっており，初期ブランクサイズ(長さ $650 \mathrm{~mm}$, 幅 $380 \mathrm{~mm}$ ) と比較すると約 $26 \%$ 削減でき，成 形後の耳は約 $74 \%$ 削減できた. また，シミュレーション上はしわも割れもなく成形できていることがわかる. 次 に図 13 に示寸 S-VBHF の最適軌道について考察すると, S-VBHF の最適軌道は交差を繰り返していることがわか る. 成形初期段階では, $\mathrm{VBHF}_{2}$ を弱くすることで材料の流入を促す一方, $\mathrm{VBHF}_{1}$ は高くすることでしわの発生を 抑えている. 第二段階において, BHF はともに小さくなるが BHF の大小関係の入れ替えが起き, $\mathrm{VBHF}_{1}$ 側で材 料は積極的に流入させ， $\mathrm{VBHF}_{2}$ 側でしわを抑えている. 最終段階においては, BHF ともに高くなるが，再度 BHF の大小関係の入れ替えが起き, $\mathrm{VBHF}_{1}$ 側でしわを抑え, $\mathrm{VBHF}_{2}$ 側で材料の流入をさせて成形は終了している. BHF の大小関係の入れ替えがない場合を想定すると，片側に高い BHF(もしくは低い BHF)が作用し続けると，割 れ(もしくはしわ)が発生することが予想され, 本論文で得られた分割可変ブランクホルダーカの最適軌道は, 成 形不良なく成形するために, 材料の流入を最適に制御していると考えられる. S-VBHF の最適軌道による FLD の 結果を図 14 に示す.この結果から, シミュレーション上ではしわや割れが発生する危険性は少ないことがわかる.
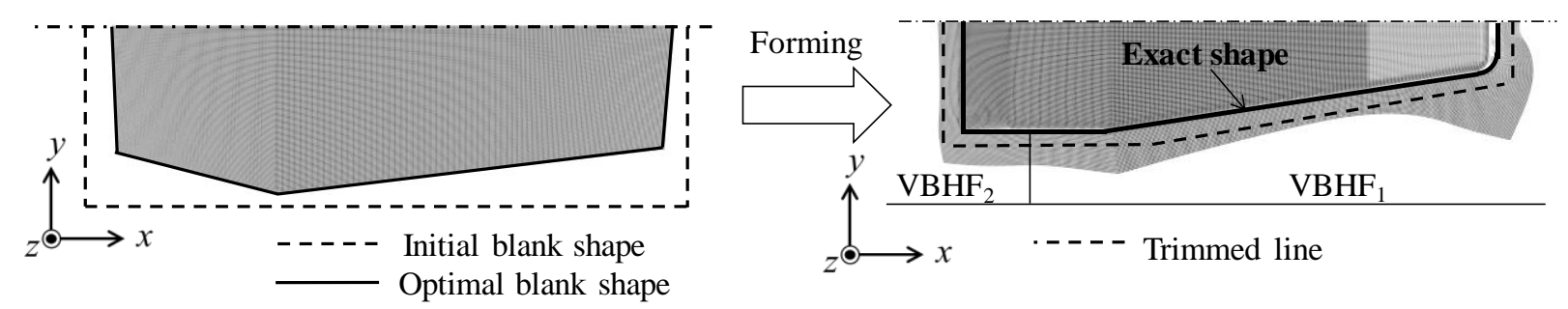

Fig. 12 Optimal blank shape and deformed shape

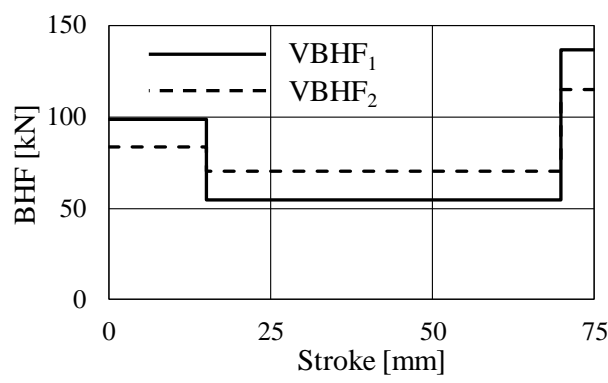

Fig. 13 Optimal segmented variable blank holder force trajectories

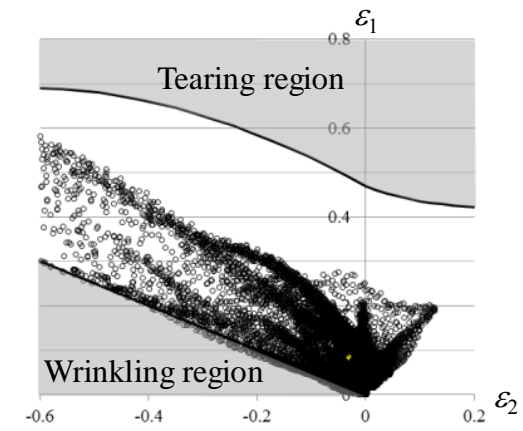

Fig. 14 Forming limit diagram using optimal segmented variable blank holder force trajectories

\section{$4 \cdot 2$ サーボプレスを用いた検証実験結果}

シミュレーション結果を用いて，ACサーボプレス(H2W300，コマツ産機)で検証実験を行った結果を図 15，16 に示す. 図 15 は初期ブランクの最適形状を用いた結果であり, 図 16 の実線は S-VBHF の最適軌道(計測值)であ 
り，点線がシミュレーションで得られた最適軌道(図 13)を表している，なお，同図(a)は図 1 の Blank holder 1 の最 適軌道, 図(b)は Blank holder ${ }_{1}$ の最適軌道である. また, 図 5 に示した引き込み量について, シミュレーションと 実駼結果の誤差を表 3 に示寸. 図 16 から，成形初期段階ではBHF が高い段階からスタートしているため，シミ ユレーションで得られた荷重に対し，BHF の追従性に若干の遅れが見られるが，その後のBHF の追従性が高い ことがわかる. また, 表 3 から寸法精度の高い結果が得られており, 本論文で目指した初期ブランクと S-VBHF 軌道の同時最適化の妥当性を確認することができる.

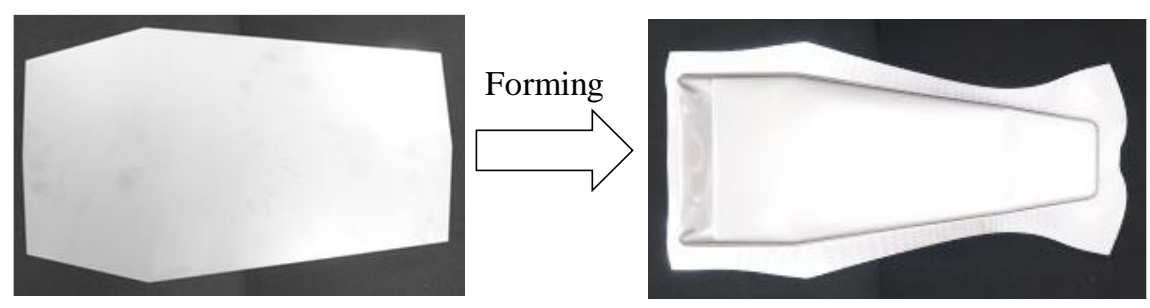

Fig. 15 Experimental result

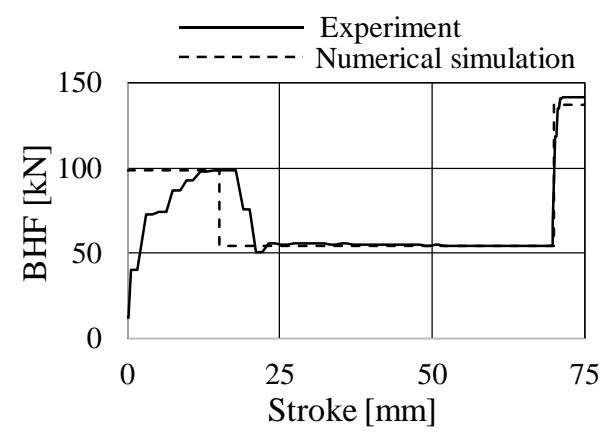

(a) VBHF trajectory of blank holder 1

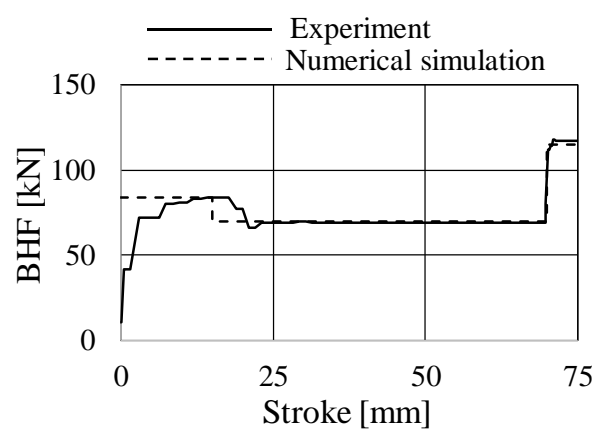

(a) VBHF trajectory of blank holder 2

Fig. 16 Experimental result of the optimal segmented variable blank holder force trajectories using AC servo press

Table 3 Dimension error between numerical simulation and experiment

\begin{tabular}{c|c|c|c|c|c}
\hline & A & B & C & D & E \\
\hline Numerical simulation [mm] & 20.7 & 69.2 & 22.7 & 36.1 & 20.7 \\
\hline Experiment [mm] & 22.4 & 71.6 & 20.7 & 31.7 & 19 \\
\hline Error [\%] & 7.6 & 3.4 & 9.7 & 13.9 & 8.9 \\
\hline
\end{tabular}

\section{$4 \cdot 3$ 分割ブランクホルダーカの優位性}

著者らの研究グループでは, 薄板成形におけるVBHFの最適軌道設計に関する研究を継続的に行ってきており, シミュレーションとサーボプレスによる実験を通じ，その有用性を検証してきている(Kitayama et al., 2010, Kitayama et al., 2012; Kitayama et al., 2013, Kitayama et al., 2016). 本論文で用いた S-VBHFによる成形法については, 国内外の学術論文を調べてみても研究報告が極めて少なく, 検証実験まで行った研究論文は著者らの調べる限り ない。ここでは，これまでの研究結果を踏まえ，S-VBHF による成形がどのような部品形状に対して優位性を発 揮できるかを記述してみたい.

はじめに記述した通り，産業界では成形中に一定のBHF を用いて成形している場合がほとんどである. 成形中 に一定の BHF を使う場合に比べ, VBHF の最適軌道による成形では, しわや割れなく成形できるばかりでなく, 成形に要する成形エネルギを大幅に削減できるといった利点を有している，比較的小型で，部品形状も対称性を 考慮しや寸い部品であれば，一定 BHF やVBHF による成形でも可能であるが，自動車のパネル等に代表される 大型かつ複雑形状の部品になると，一定 BHF や VBHF による成形では，ある部分では板厚減少が激しくなり， 
別の部分ではしわが発生するといった状況が起こりうる．このような部品形状に対し，高品質の薄板部品を作る ためには, S-VBHFによる成形は有効な成形法であり, その最適軌道設計は本論文で示した方法で決定できる.

\section{5. おわりに}

本論文では，成形後の耳を最小とするような初期ブランク形状と，しわと割れが発生しないような分割可変ブ ランクホルダーカの同時最適化を行った．分割可変ブランクホルダー力の最適軌道設計に関しては，一方のブラ ンクホルダーカが他方のブランクホルダーカを制約することを考慮した方法を提案した．また，初期ブランク形 状については，有限個の制御点を設定し，移動方向を規定することで，設計変数の増加を抑えたブランク形状を 表現する方法を提案した，成形限界線図と引き込み量を基本としたシミュレーションモデルを構築し，そのシミ ユレーションモデルを用いて, 逐次近似最適化によって, 初期ブランクの最適形状と分割可変ブランクホルダー 力の最適軌道を決定し， $\mathrm{AC}$ サーボプレス(H2W300，コマツ産機)を用いて検証実験を行った. 実験結果から，整 合性の高い結果を得ることができた。自動車部品等の複雑な成形品に対し，成形不良なく成形するためには分割 可変ブランクホルダーカは極めて有効な方法の一つであり, 本論文では初期ブランク形状と分割可変ブランクホ ルダー力の同時最適化を行い, シミュレーション結果に留まることなく, 検証実験を通じその有効性を示したこ とは，今後の先進的薄板成形技術の発展につながると大いに期待できる.

\section{References}

Chamekh, A., BenRhaiem, S., Khaterchi, H., BelHadjSalah, H. and Hambli, R., An optimization strategy based on a metamodel applied for the prediction of the initial blank shape in a deep drawing process, International Journal of Advanced Manufacturing Technology, Vol. 50 (2010), pp. 93-100.

Fazli, A. and Arezoo, B., A comparison of numerical iteration based algorithms in blank optimization, Finite Elements in Analysis and Design, Vol. 50 (2012), pp. 207-216.

Hino, R., Yoshida, F. and Toropov, V.V., Optimum blank design for sheet metal forming based on the interaction of high- and low-fidelity FE models, Archive of Applied Mechanics, Vol. 75, No. 10 (2006), pp. 679-691.

Jakumeit, J., Herdy, M. and Nitsche, M., Parameter optimization of the sheet metal forming process using an iterative parallel Kriging algorithm, Structural and Multidisciplinary Optimization, Vol. 29 (2005), pp. 498-507.

Kitayama, S., Hamano, S., Yamazaki, K., Kubo, T., Nishikawa, H. and Kinoshita, H., A closed-loop type algorithm for determination of variable blank holder force trajectory and its application to square cup deep drawing, International Journal of Advanced Manufacturing Technology, Vol. 51 (2010), pp. 507-571.

Kitayama, S., Arakawa, M. and Yamazaki, K., Sequential approximate optimization using radial basis function network for engineering optimization, Optimization and Engineering, Vol. 12, No. 4 (2011), pp. 535-557.

Kitayama, S., Kita, K. and Yamazaki, K., Optimization of variable blank holder force trajectory by sequential approximate optimization with RBF network, Journal of Advanced Manufacturing Technology, Vol. 61, No. 9-12 (2012), pp. 1067-1083.

Kitayama, S., Srirat, J., Arakawa, M. and Yamazaki, K., Sequential approximate multi-objective optimization using radial basis function network, Structural and Multidisciplinary Optimization, Vol. 48, No. 3 (2013), pp. 501-515.

Kitayama, S., Saikyo, M., Kawamoto, K. and Yamamichi, K., Multi-objective optimization of blank shape for deep drawing with variable blank holder force via sequential approximate optimization, Structural and Multidisciplinary Optimization, Vol. 52, No. 2 (2015), pp. 1001-1012.

Kitayama, S., Koyama, H., Kawamoto, K., Noda, T., Yamamichi, K. and Miyasaka, T., Numerical and experimental case study on simultaneous optimization of blank shape and variable blank holder force trajectory in deep drawing, Structural and Multidisciplinary Optimization (2016), DOI: 10.1007/s00158-016-1484-4.

Lin, Z.Q., Wang, W.R. and Chen, G.L., A new strategy to optimize variable blank holder force towards improving the forming limits of aluminum sheet metal forming, Journal of Materials Processing Technology, Vol. 183 (2007), pp. 339-346.

Liu, Y., Chen, W., Ding, L. and Wang, X., Response surface methodology based on support vector regression for polygon blank shape optimization design, International Journal of Advanced Manufacturing Technology, Vol. 66 (2013), pp. 1397-1405.

Lo, S.W. and Yang, T.C., Closed-loop control of the blank holding force in sheet metal forming with a new embedded-type 
displacement sensor, International Journal of Advanced Manufacturing Technology, Vol. 24 (2004), pp. 553-559.

Oliveira, M.C., Padmanabhan, R., Baptista, A.J., Alves, J.L. and Menezes, L.F., Sensitivity study on some parameters in blank design, Materials and Design, Vol. 30 (2009), pp. 1223-1230.

Park, S.H., Yoon, J.H., Yang, D.Y. and Kim, Y.H., Optimum blank design in sheet metal forming by the deformation path iteration method, International Journal of Mechanical Science, Vol. 41 (1999), pp. 1217-1232.

Sheng, Z.Q., Jirathearanat, S. and Altan, T., Adaptive FEM simulation for prediction of variable blank holder force in conical cup drawing, International Journal of Machine Tools \& Manufacturing, Vol. 44 (2004), pp.487-493.

Vafaeesefat, A., Finite element simulation for blank shape optimization in sheet metal forming, Materials and Manufacturing Processes, Vol. 26 (2011), pp. 93-98.

Wang, W.R., Chen, G.L., Lin, Z.Q. and Li, S.H., Determination of optimal blank holder force trajectories for segmented binders of step rectangle box using PID closed-loop FEM simulation, International Journal of Advanced Manufacturing Technology, Vol. 32 (2007), pp. 1074-1082.

Wang, H., Li, G., Yao, Z. and Zhi, H., Optimization of sheet metal forming processes by adaptive response surface based on intelligent sampling method, Journal of Materials Processing Technology, Vol. 197 (2008), pp. 77-88.

Wang, H., Li, E. and Li, G.Y., Parallel boundary and best neighbor searching sampling algorithm for drawbead design optimization in sheet metal forming, Structural and Multidisciplinary Optimization, Vol. 41 (2010), pp. 309-324.

Wang, J., Goel, A., Yang, F. and Gau, J.T., Blank optimization for sheet metal forming using multi-step finite element simulations, International Journal of Advanced Manufacturing Technology, Vol. 40 (2009), pp. 709-720. 